\title{
POBLEMATIKA ALUMNI PAI SEBAGAI GURU KELAS DI MADRASAH IBTIDAIYAH SEKECAMATAN PANGKALAN SUSU KABUPATEN LANGKAT
}

\author{
Roys Afreni \\ Penulis adalah Guru di Madrasah Ibtidaiyah Sekecamatan Pangkalan Susu \\ Kabupaten Langkat \\ E-mail: afrenir@gmail.com
}

\begin{abstract}
This study was conducted with regard to the phenomenon of Islamic religious education graduates who became class teachers in Madrasah Ibtidaiyah Pangkalan Susu distric. The purpose of this research is to know: 1) Problematic graduates of PAI as classroom teachers in planning instructional. 2) Problematic graduates of PAI as classroom teachers in implementing instructional. 3) Problematic graduates of PAI as classroom teachers in conducting instructional evaluation. The type of research is using qualitative research methods with phenomenology approach. The subject of research is the graduate of Islamic Religious Education who has become a class teacher. The result of the research that problematic of PAI graduates as teacher of Madrasah Ibtidaiyah class in planning instructional in Pangkalan Susu sub-district of Langkat district is still having difficulties to make instructional plan independently. Besides these three Madrasah Ibtidaiyah also do not have a library that can provide books that qualified to be used as a source of learning. While in implementing the instructional is the similarity of teachers in the method of learning and the lack of mastery of the material. This is due to their lack of knowledge about the variety of instructional methods and the lack of mastery of the material. On the other hand these teachers rarely attend training, seminars, workshops that can provide information for development for their profession. As for the evaluation of learning is not yet meet the assessment procedures. This is because the teacher has not understood the way the preparation of the implementation Plan of instructional.
\end{abstract}

\section{KeyWord : Problematics, Graduates of Islamic religious education graduates}

\section{PENDAHULUAN}

Alumni Pendidikan Agama Islam merupakan alumni terbanyak tiap tahunnya yang dihasilkan lembaga pendidikan tinggi Islam sebagaimana Universitas Islam Negeri Sumatera Utara. Keadaan ini menyebabkan mereka menerima tawaran peluang untuk mengajar bidang studi apa saja walau itu tidak sesuai dengan latar belakang pendidikan mereka. Kerana dalam sebuah sekolahan biasanya telah ada seorang guru yang bekerja mengajar di situ (fakta kampus: 2017). Dan menurut Undang-Undang Nomor 14 tahun 2005 tentang Guru dan Dosen pasal 8 bahwa Guru wajib memiliki kualifikasi akademik, kompetensi, dan sertifikasi. 
Alumni-alumni tersebut tidak menghiraukan latar belakang pendidikan mereka, karena menganggap mereka dulu juga pernah belajar bidang studi lainnya. Seperti dijelaskan Purwanto, (2007: 4) Kebanyakan orang masih menganggap enteng dan mudah terhadap hal mendidik itu. Mereka beranggapan bahwa kepandaian mendidik itu sudah dengan sendirinya akan dipunyai oleh setiap orang dari pergaulannya dengan anak-anak, mereka percaya bahwa dalam setiap situasi,"intuitif" akan mendapat sikap dan tindakan yang tepat.

Guru-guru alumni PAI yang dijadikan guru kelas ini terlihat dari data guru serayon Madrasah Ibtidaiyah Negeri Bukit Jengkol kecamatan Pangkalan susu. Secara kualifikasi akademik selayaknya ini tidak dilakukan, karena out put dari guru PAI itu adalah mengajarkan bidang studi agama. Ada empat bidang studi yang harus diajarkan guru PAI, yaitu akidah akhlak, alquran hadis, sejarah kebudayaan Islam, dan fiqih. Sebagaimana UU Sistem Kependidikan Nasional No. 20 Tahun 2003, Pendidik adalah tenaga kependidikan yang berkualifikasi sebagai guru, dosen, konselor, pamong belajar, widyaiswara, tutor, instruktur, fasilitator, dan sebutan lain yang sesuai dengan kekhususannya, serta berpartisipasi dalam menyelenggarakan pendidikan.

Semangat para alumni PAI ini dalam melaksanakan program-program pendidikan baik ekstrakurikuler maupun akademik diakui oleh kepala rayon Madrasah Ibtidaiyah sekecamatan Pangkalan Susu telah sejak tahun 2005 ke atas, mengingat masa itu beberapa mereka telah menjadi tenaga honorer, dan masa bakti mereka yang lama menjadi nilai lebih untuk mengampu bidang studi selain materi Pendidikan Agama Islam. Memang sebenarnya fakultas tarbiyah Universitas Islam Negeri Sumatera Utara pun telah pernah membuka S1 kedua untuk guru-guru MI di lingkungan Kementerian Agama di beberapa kabupaten, tepatnya tahun 2007 sayangnya berlangsung tidak lama. Program ini merupakan kebijakan pemerintah di masa itu. Sebagaimana Munajat, (2014: 257) menjelaskan program ini dilaksanakan oleh Perguruan Tinggi Agama Islam (PTAI), yang dalam proses perkuliahannya menggunakan pendekatan dual mode system melalui pengintegrasian sistem pembelajaran konvensional (tatap muka di kampus) dan sistem pembelajaran mandiri.

Sekali lagi alumni PAI yang telah mengampu bidang studi umum ini belum terjaring untuk mengikuti salah satu program peningkatan kualifikasi sarjana (S1) di bawah naungan Kementerian Agama. Hal ini sebagaimana tercantum dalam (KMA: 2008) mensukseskan program tersebut secara maksimal, maka segala bentuk 
penyelenggaraan program ini telah sepenuhnya dilaksanakan dengan mempedomani Regulasi Penyelenggaraan Program peningkatan kualifikasi sarjana (S.1) melalui Dual Mode System yang diterbitkan Direktorat Pendidikan Tinggi Islam dengan merujuk pada Keputusan Menteri Agama RI Nomor 179 tahun 2008 tentang Penyelenggaraan Kualifikasi Sarjana (S.1) bagi Guru RA, Guru Madrasah dan Guru PAI melalui Dual Mode System.

Madrasah Ibtidaiyah swasta maupun negeri di kecamatan Panglakan Susu selain menjadikan alumni-alumni PAI ini sebagai guru kelas yang mengampu bidang studi umum juga sebagai guru Pendidikan Agama Islam, ada yang mengampu bidang studi fikih, alquran hadis, bahkan bahasa arab, dengan alasan jumlah guru belum memadai, belum ada dana sekolah untuk menambah guru, atau mencukupkam jam mengajar bagi yang telah mendapat tunjangan sertifikasi. Ini membuktikan bahwa pemilihan guru di sekolah- sekolah Islam sering kali kurang memperhatikan keahlian (Ahmad, 2011: 81).

Selain itu awalnya sebagian perekrutan guru-guru dari Madrasah Ibtidaiyah di kecamatan Pangkalan susu agar dapat membantu pengembangan madrasah-madrasah tersebut, karena sebagian mereka memiliki keahlian pada bidang non akademik, ada yang sebagai pelatih tilawatil alquran, pelatih drum band, nasyid dan pelatih kaligrafi. Alumni-alumni PAI ini dianggap bisa menyahuti visi dan misi madrasah. Sebagaimana Sutrino, (2009: 6) mengatakan "proses rekrutmen sumber daya manusia tidak boleh diabaikan, hal ini disebabkan untuk menjaga supaya tidak terjadi ketidaksesuaian antara apa yang diinginkan dan apa yang didapat”. Senada dengan hal ini Janawi (2012: 30) untuk meningkatkan kualitas pendidikan seorang pendidik harus memiliki kompetensi umum dan kompetensi khusus sesuai dengan jenjang dan jenis pendidikan yang ditekuni.

Ketidak sesuaian bidang studi yang diampu seorang guru dengan latar belakang pendidikannya akan berdampak pada prestasi siswa. Berdasarkan data yang diperoleh selama enam tahun terakhir belum ada lagi prestasi yang dapat diraih siswa/siswi serayon Madrasah Ibtidaiyah negeri Bukit Jengkol kecamatan Pangkalan susu di bidang akademik khususnya bidang excat, (Bahasa Indonesia, Matematika, Ilmu Pengetahuan Alam) kecuali di tahun 2012 pernah meraih juara tiga untuk bidang sain di tingkat kabupaten. Oleh karena itu, Oemar (2006: 117-118) mengatakan bahwa "Jabatan guru dikenal sebagai suatu pekerjaan profesional, artinya jabatan ini 
memerlukan suatu keahlian khusus. Sebagaimana orang menilai dokter, insinyur, ahli hukum, dan sebagainya sebagai profesi tersendiri”. Selanjutnya menurut Janawi (2012: 66) guru dituntut untuk memenuhi berbagai persyaratan yang sangat dibutuhkan dalam proses pendidikan agar guru dapat melaksanakan tugasnya dengan baik dan pada akhirnya akan mencapai hasil yang maksimal sebagaimana tujuan akhir pendidikan. Begitu pula menurut Marlina (2016: 27) bahwa keberhasilan proses belajar mengajar dalam mencapai tujuan pembelajaran sangat ditentukan oleh guru.

Aspek-aspek Pendidikan bermutu salah satunya adalah tenaga pendidikan atau guru yang memegang peranan penting dalam membentuk dan mempersiapkan peserta didik yang handal baik dari sikap, pengetahuan dan keterampilan. Guru adalah sosok penyampai ilmu yang bertujuan kepada pembentukan sikap, pengetahuan dan keterampilan peserta didiknya yang optimal. Sebagaimana Nasution, (2017: 1) menjelaskan guru memainkan peranan yang sangat penting dalam meningkatkan kualitas pendidikan. hal senada juga dikemukakan Jakaria (2014: 500) banyak faktor yang mempengaruhi kualitas proses dan hasil pendidikan, antara lain kurikulum, guru, sarana dan prasarana pendidikan, lingkungan, manajemen pendidikan, dan potensi anak itu sendiri. Namun dari berbagai faktor yang mempengaruhi kualitas pendidikan, faktor guru merupakan faktor yang penting, bahkan dapat dikatakan sebagai faktor kunci dalam keberhasilan pendidikan.

Guru pada tingkat dasar juga sebagai pamong karena usia MI/SD adalah usia yang memerlukan pengawasan terutama di kelas awal 1, 2, dan tiga gerak dan perilaku belum terkontrol dengan sendirinya, saat ini pengawasan atau pamong guru dibutuhkan agar peserta didik terhindar dari accident yang menyebabkan bahaya bagi mereka. Pada saat ini anak-anak juga sangat tertarik untuk mengetahui segala sesuatu, mereka sangat sulit untuk berdiam diri, mereka belajar sesuatu terutama yang berhubungan dengan fisik, seperti berolahraga, berlari, berenang, mengumpulkan segala sesuatu, dan mengembara sampai ke batas yang disetujui bahkan yang tidak disetujui guru/orang tua (Masganti 2012: 114-115).

Lebih lanjut Usman, (1992: 1) menjelaskan "Guru merupakan jabatan atau profesi yang memerlukan keahlian khusus. Jabatan dan keahlian khusus guru merupakan keterampilannya dalam merancang pembelajaran, memahami pendekatan yang sesuai bagi bermacam-macam karakteristik peserta didik, untuk menguasai 
materi atau bahan ajar, dan melakukan penilaian yang meliputi sikap spiritual, sosial, pengetahuan dan keterampilannya secara berkelanjutan.

Pekerjaan guru semakin banyak digemari saat ini, ada beberapa alasan diantaranya pekerjaan simpel, dikenal orang, mendapat tunjangan sertifikasi, dan lainnya. Sebagaimana Syafaruddin, (2018: 1) menjelaskan meskipun, pada mulanya profesi guru kurang begitu menarik bagi anak-anak bangsa. Namun setelah implementasi kebijakan peningkatan profesionalitas guru melalui sertifikasi yang berdampak pada peningkatan kesejahteraan (tunjangan profesi), maka pendidikan keguruan pada perguruan tinggi semakin diminati.

Dengan tingkat pertumbuhan lapangan kerja yang rendah profesi guru menjadi salah satu alternatif orang untuk mendapatkan pekerjaan. Maka sering kita dapati istilah guru jadi-jadian atau guru jadilah bukan sebaliknya jadilah guru. Padahal seharusnya guru/pendidik dituntut menguasai masalah-masalah profesional dan akademik. Sebagaimana disebutkan dalam Undang-Undang Republik Indonesia Nomor 20 Tahun 2003 Tentang Sistem Pendidikan Nasional pasal 42: "Pendidik harus memiliki kualifikasi minimum dan sertifikasi sesuai jenjang kewenangan mengajar, sehat jasmani dan rohani, serta memiliki kemampuan untuk mewujudkan tujuan pendidikan nasional".

Madrasah Ibtidaiyah, yang selanjutnya disingkat MI, adalah salah satu bentuk satuan pendidikan formal dalam binaan Kementerian Agama yang menyelenggarakan pendidikan umum dengan kekhasan agama Islam pada jenjang pendidikan dasar (Pedoman, 2013: 37). Beberapa kondisi objektif madrasah saat ini diantaranya, kualitas lulusan yang masih agak tertinggal untuk melanjutkan keperguruan tinggi, kurangnya penguasaan keilmuan dan keterampilan, kualitas madrasah secara umum masih memprihatinkan, sebagian besar guru unqualified dan mismatch (salah jurusan), kekurangan tenaga kependidikan (Tata Usaha, Pustakawan dll). Pada madrasahmadrasah negeri sudah banyak yang memenuhi sarana dan prasarana tersebut. Sedangkan pada madrasah-madrasah swasta pemenuhan hal-hal di atas masih seadanya, hal ini karena pengadaan sarana dan prasarana adalah hasil swadaya masyarakat sedang bantuan dari pemerintah sangat kecil.

Madrasah-madrasah ibtidaiyah di kecamatan Pangkalan susu sebelumnya belum mendapat sambutan baik karena ketidakpahaman masyarakat akan lembaga pendidikan ini. Setelah beberapa tahun ini didukung dengan peningkatan mutu 
komponen-komponennya, baik dari segi manajemen dan kebijakan kepala madrasah di bidang sarana dan prasarana, terselengaranya program-program unggulan para peserta didiknya, keberhasilan madarasah membawa nama dari tingkat kecamatan sampai nasional yang tidak lain adalah kerja keras dari beberapa komponen tersebut. Jadi untuk mengatasi kendala dalam manajemen mutu, perlu dilandasi oleh perubahan sikap dan cara bekerja. Pemimpin harus memotivasi bawahannya agar bekerja lebih baik. Misalnya dengan jalan menciptakan iklim kerja yang menyenangkan, menyediakan sarana yang memadai, menetapkan sistem prosedur kerja yang jelas, serta memberi penghargaan atas keberhasilan dan prestasi bawahan (Deden, 2016: 35).

Ketua Rayon Madrasah Ibtidaiyah Kecamatan Pangkalan susu menjelaskan salah satu faktor alumni-alumni PAI ini menjadi guru kelas adalah lamanya masa mengajar mereka di madrasah-madrasah tersebut bahkan sebagian telah memiliki sertifikat pendidik sebagai guru kelas, diantara mereka telah mengajar dari tahun 2000 sedangkan regulasi pemerintah tentang program peningkatan kualifikasi sarjana melalui Dual Model System yang pernah ada di tahun 2008 dilaksanakan namun mereka tidak terjaring untuk mengikuti program tersebut. Sebagaimana juga menurut Peraturan Pemerintah Nomor 46 (Pasal 4 Ayat 4) 2016 tentang Penatapan Liniearitas Guru Bersertifikat Pendidik.

Madrasah Ibtidaiyah sebagai salah satu lembaga pendidikan setingkat SD yang dalam pelaksanaan pembelajarannya juga tidak terlepas dari beberapa permasalahan. Ada beberapa alumni PAI ini ketika diwawancarai mengaku sulit untuk melaksanakan pembelajaran bidang studi umum, sehingga akhirnya musyawarah diantara mereka saling tukar posisi untuk mengajarkan bidang studi-bidang studi tersebut. Hal ini seharusnya tidak terjadi, sebab guru merupakan salah satu komponen dalam sistem pendidikan, bila salah satu komponen tak dapat berfungsi dengan baik maka akan berakibat buruk pula bagi sektor lain. Sebagaimana Munirah, (2015: 234) menjelaskan komponen-komponen tersebut bekerja secara bersama-sama, saling terkait dan mendukung dalam mencapai tujuan pendidikan. Lebih lanjut Fuad (2017: 23) menegaskan bahwa guru merupakan sumber daya utama dalam upaya pengembangan potensi peserta didik di masa depan. Karena itu, penyandang profesi guru bermakna strategis, karena mengemban tugas sejati bagi proses pemanusiaan, pencerdasan, pembudayaan, penanam nilai dan dan pembangun karakter bangsa. 
Tiga Madrasah Ibtidaiyah di kecamatan Pangkalan Susu baru dua madrasah saja yang menggunakan kurikulum 2013 yaitu Madrasah Ibtidaiyah negeri Bukit Jengkol dan Madrasah Ibtidaiyah swasta Al-Washliyah sedangkan Madrasah Ibtidaiyah Swasta Pintu Air belum menerapkannya dengan alasan guru merasa kesulitan untuk mengikuti perubahan kurikulum. Dari sini peneliti menemukan kesenjangan di lokasi penelitian terkait dengan pendidik beserta tugas pokok dan fungsinya.

Lebih lanjut terdapat informasi salah satu wali murid dari Madrasah Ibtidaiyah kecamatan Pangkalan Susu ini pernah menanyakan pekerjaan rumah mata pelajaran matematika putrinya, saat itu terdapat perbedaan persepsi antara ia dan guru kelas, kebetulan lagi si wali murid berprofesi sebagai guru matematika di sekolah lanjutan. Masalah ini tidak akan terjadi bila guru memiliki pengasaan penuh pada materi pokok atau bahan ajar yang diberikan karena guru dengan kompetensi profesionalnya akan menyajikan materi pokok secara konferehensif, sebagaimana Nasution, (2018: 2) menjelaskan oleh karena itu, kompetensi atau kemampuan profesional guru akan memberikan sesuatu yang positif yang berkenaan dengan keberhasilan prestasi belajar peserta didik baik pada aspek afektif, kognitif maupun psikomotorik.

Guru kelas madrasah ibtidaiyah yang alumni PAI ini juga mengajarkan bidang studi umum seperti matematika sedikit metode, strategi yang dimilikinya jelas tidak sama porsinya dengan guru mata pelajaran yang memiliki cara, dan metode dalam membelajarkan materi-materi pelajaran matematika tersebut. Sebagaimana menurut Bahiyyah (2016: 9) dengan minimnya pengetahuan dan pemahaman terhadap teori, metode dan strategi pembelajaran, pendidik cenderung menggunakan pembelajaran satu arah sehingga tingkat efektifitasnya rendah.

Selanjutnya Kepala Madrasah mengambil kebijakan dengan merotasi guru yang ada untuk mengantisipasi masalah ini. Namun kondisi jumlah siswa yang banyak dan mengingat belum ada lagi tenaga pengajar lain, hal ini masih berjalan. Dari sini, guru harus up to date agar tidak ketinggalan zaman tapi harus mengikuti perubahan dunia. Guru harus mampu membuktikan dirinya sebagai sosok pembaru yang dinamis, responsif, progresif, produktif, dan kompetitif. Usaha maksimal menuju level professional harus diperjuangkan. Hal ini tidak bisa ditunda-tunda, mengingat tantangan globalisasi sudah sedemikian dahsyatnya didepan mata (Jamal (2009: 16). Lebih lanjut Oemar, (2014: 58) menjelaskan peranan guru sangat dominan, dia 
menentukan segala hal yang dianggap tepat untuk disajikan pada siswanya. Guru dipandang sebagai orang yang serba mengetahui, berarti guru adalah yang paling pandai. Dia mempersiapkan tugas-tugas, memberikan latihan-latihan dan menentukan peraturan dan kemajuan tiap siswa.

\section{KAJIAN TEORI}

Problematika adalah masalah-masalah yang menjadi persoalan dan masih belum dapat dipecahkan. Definisi problematika sangat bervariasi sebagaimana para ahli mencoba mendefinisikan tentang problematika. Seperti dijelaskan Sugiyono (2010: 23) masalah adalah merupakan penyimpangan antara yang seharusnya dengan yang terjadi, antara aturan dengan pelaksanaan, antara teori dengan praktek, antara rencana dan pelaksanaan.

Secara sederhana Kamus Besar Bahasa Indonesia, (2002: 276) mengartikan setiap yang menimbulkan permasalahan juga disebut problema atau problematika. Lebih lanjut problematika dalam konteks Al-quran yaitu dapat yang berasal dari sebuah pertanyaan dapat juga yang berasal dari sebuah peristiwa. Salah satu ayat tentang pertanyaan sebagaimana Al-quran surat Al-Isra 17: 85. "dan mereka bertanya kepadamu tentang roh. Katakanlah: "Roh itu Termasuk urusan Tuhan-ku, dan tidaklah kamu diberi pengetahuan melainkan sedikit".

Sebagai lembaga pendidikan yang berpatokan pada kurikulum dalam melaksanakan kegiatan pembelajarannya ini dapat terlihat dari visi dan misi ketiga Madrasah Ibtidaiyah. Visi dan misi sebuah sekolah bukan hanya sebuah semboyan belaka melainkan sebuah rumusan yang aplikatif untuk tercapainya tujuan pendidikan dari penyelengaraan lembaga pendidikan tersebut.

Madrasah Ibtidaiyah Negeri Bukit Jengkol memiliki visi dan misi yang telah menghantarkannya sebagai sekolah berprestasi di tingkat nasional dengan predikat sebagai sekolah Adiwiyata, yaitu sebagai sekolah yang layak untuk menyelenggarakan kegiatan belajar mengajar dengan mewujudkan rasa kepedulian terhadap lingkungan sekitar. Seluruh warga sekolah yang membiasakan rasa kepedulian terhadap lingkungannya akan terpatri dalam diri peserta didiknya. Program ini tidak saja menyiapkan sekolah sendiri sebagai penyandang gelar adiwiyata namun mampu mengadakan pembinaan sekolah lain dalam meningkatkan kinerja program ini yang berdampak positif terdap perlindungan dan pengelolaan lingkungan hidup. 
Adapun temuan dari konsep visi dan misi Madrasah Ibtidaiyah Swasta AlWashliyah dan Madrasah Ibtidaiyah Swasta Pintu Air tentu belum seperti MIN Bukit Jengkol karena memiliki keterbatasan baik sarana dan prasarananya. Terlihat dari jumlah peserta didik antara madrasah negeri dan swasta sangat berbanding jauh. Bahkan tak jarang mereka pihak swasta memberikan penawaran serba gratis untuk menarik hati masyarakat agar mau menyekolahkan anak-anaknya. Karena mengingat ada beberapa guru di situ yang telah tersefrtifikasi dan harus mengajar dengan memenuhi jumlah rasio peserta didiknya. Serta mengandalkan biaya operasional sekolah (BOS) yang ada. Padahal pendidikan bukan sekedar memenuhi standar rasio jumlah peserta didik saja maupun BOS yang didapat, tapi sekali lagi harus tetap mengacu pada 8 standar pendidikan nasional yang setiap suatu lembaga pendidikan harus memenuhinya.

\section{METODE PENELITIAN}

Metode penelitian yang digunakan adalah penelitian kualitatif. Penelitian yang dilakukan pada pada tiga sekolah/madrasah ibtidiyah di kecamatan Pangkalan Susu, 1) MIN Bukit Jengkol, 2) MIS Al-Washliyah, dan 3) MIS Pintu Air. Focus dan subfokus penelitian ini adalah: (1) problematika Alumni PAI Sebagai Guru Kelas Madrasah Ibtidaiyah dalam Merencanakan Pembelajaran di Kecamatan Pangkalan Susu, (2) problematika Alumni PAI Sebagai Guru Kelas Madrasah Ibtidaiyah dalam Melaksanakan Pembelajaran di Kecamatan Pangkalan Susu, dan (3) problematika Alumni PAI Sebagai Guru Kelas Madrasah Ibtidaiyah dalam Melakukan Evaluasi Pembelajaran di Kecamatan Pangkalan Susu.

\section{TEMUAN DAN PEMBAHASAN PENELITIAN}

Masalah alumni PAI sebagai guru kelas dalam melakukan evaluasi pembelajaran di kecamatan Pangkalan Susu kabupaten Langkat adalah belum memenuhi prosedur penilaian. Hal ini disebabkan guru belum melakukan perubahan dalam penyampain materi kepada peserta didik terutama merencanakan pelaksanaan pembelajaran atau menyusun RPP. Sebab perencanaan pembelajaran merupakan titik awal dari evaluasi pembelajaran dan bila guru telah memahami betul cara penyusunan RPP maka bentuk evaluasi pembelajaran akan tersusun secara sistematis karena 
menurut Yusuf (2015: 151) apa yang diamati dan dievaluasi sebenarnya adalah apa yang dilakukannya dalam kegatan pembelajaran dalam kaitannya dengan RPP.

Hasil temuan yang diperoleh dari penelitian ketiga sekolah ini secara umum kecendrungan daripada problematika alumni PAI sebagai guru kelas dalam bidang perencanaan itu adalah guru mengalami kesulitan dalam menyusun rencana pelaksanaan pembelajaran secara mandiri dan pembelajaran diisi dengan satu atau dua buku sebagai sumber belajar. Hal ini disebabkan kurangnya pengetahuan mereka dalam mempersiapkan seluruh kegiatan pengajaran atau pembelajaran dan tidak terdapatnya perpustakaan yang menyediakan buku-buku mumpuni sebagai sumber belajar. Padahal seharusnya setiap kegiatan pembelajaran harus berdasarkan perencanaan yang sejalan dengan prinsip kurikulum yang ada. Karena pada kurikulum dan kegiatan pembelajaran terdapat maksud atau tujuan pendidikan.

Sebagaimana dikatakan Latif (2014: 1) kurikulum merupakan rancangan pendidikan yang merangkum semua pengalaman belajar yang disediakan bagi siswa di sekolah. Lebih lanjut Yusuf (2015: 120) yang mengatakan konsep kurikulum adalah segala sesuatu yang menjadi tanggung jawab sekolah; atau segala sesuatu yang akan terjadi di sekolah/ dalam lembaga pendidikan yang merupakan tanggung jawab sekolah/lembaga pendidikan, baik berupa rencana/dokumen tertulis (apa yang diajarkan, bagaimana membelajarkannya, bagaimana segala sesuatu itu ditata, bagaimana menilai dan mengevaluasinya) serta proses pelaksanaan rencana atau dokumen tertulis yang telah ditetapkan.

Guru dan perencanaan pembelajaran ibarat niat dalam beribadah, yang dinyatakan dalam hati dan dibuktikan dengan kata-kata. Dalam kegiatan pembelajaran kata-kata itu layaknya RPP yang tersusun jelas apa saja yang akan dilakukan guru dalam pembelajaran. Menyusun perencanaan pelaksanaan pembelajaran salah satu kompetensi pedagogi yang harus dimiliki guru. Bila guru tadak paham menyusun RPP atau dalam arti kata hanya mengajar, masuk kelas yang penting dan mengemongi peserta didik supaya kondusif.

Sedangkan hasil temuan yang diperoleh kecenderungan problematika alumni PAI sebagai guru kelas dalam bidang pelaksanaan pembelajaran secara umumnya adalah kelemahan mereka dalam metode pembelajaran hal ini disebabkan karena kurangnya pengetahuan guru tentang variasi metode di pihak lain memang guru-guru madrasah ibtidaiyah ini jarang mengikuti workshop atau seminar tentang metode- 
metode pembelajaran yang up-todate padahal seharusnya seorang guru harus menguasai beberapa metode pembelajaran.

Maka kedepannya upaya untuk meningkatkan kompetensi guru tak lepas dari dalam diri guru itu sendiri dengan banyak cara, seperti dengan banyak membaca, dan mengambil langkah-langkah progresif secara praktis dengan memperkuat kompetensi ilmu, sebagaimana yang dikatakan Azra dalam bukunya "Pendidikan Islam Tradisi dan Modernisasi Menuju Milenium Baru" halaman 29, bahwa kebanyakan pengajar membutuhkan perbaikan lebih lanjut dalam kualifikasi mereka; meningkatkan pengetahuan mereka tentang perkembangan mutakhir.

Selanjutnya hasil temuan yang diperoleh dari problematika alumni PAI sebagai guru kelas di kecamatan Pangkalan Susu kabupaten Langkat dalam melakukan evaluasi pembelajaran pada umumnya cendrung belum memenuhi prosedur penilaian. Hal ini disebabkan guru belum mampu merencanakan pelaksanaan pembelajaran atau menyusun RPP secara mandiri. Perencanaan pembelajaran merupakan titik awal dari evaluasi pembelajaran.Urgentnya penyusunan RPP secara mandiri bagi guru-guru kelas ini menandakan mereka memahami apa yang menjadi kebutuhan peserta didik untuk mencapai sebuah tujuan pembelajaran yang telah termaktub dalam kurikulum. Saat guru memahami tuntutan kurikulum, sistem penilaian yang diberikan kepada peserta didiknya tidak berpatokan dari buku semata.

Hal ini selalu dialami guru sewaktu tugas harian yang diberikan kepada pesrta didiknya dapat dengan mudah diselesaikan oleh mereka namun ketika saat ulangan semester nilai mereka anjlok. Dan satu lagi jika guru menyadari hasil belajar peserta didik yang rendah sebagai kelemahannya dalam menyampaikan materi maka selayaknya ia mulai merancang pembelajaran ke depannya dengan tidak mengikuti gaya yang ia biasa lakukan dalam hal ini strategi dan metode guru dalam mengajar harus mengikuti kesesuain materi. Sebab tidak semua materi itu sifatnya sama. Maka bila guru dapat mengidentifikasi materi pembelajaran sesuai dengan sifatnya ia akan merancang pembelajarannya sesuai alur dari sifat materi tersebut. Sebagaimana dikatakan Sudjana dalam bukunya "Penilaian Hasil Proses Belajar Mengajar" bahwa hasil belajar pada dasarnya merupakan akibat dari suatu proses belajar, ini berarti bahwa optimalnya hasil belajar siswa bergantung pula pada proses belajar siswa dan proses mengajar guru. 


\section{SIMPULAN DAN REKOMENDASI}

1. Alumni PAI yang telah menjadi guru kelas di madrasah-madrasah ibtidaiyah kecamatan Pangkalan Susu kabupaten Langkat pada umumnya telah lama mengabdikan diri sebagai tenaga pendidik di lembaga-lembaga pendidikan tersebut. Pilihan menjadi guru kelas yang samasekali latar belakang pendidikannya belum match dengan bidang studi yang mereka ampu adalah sebuah perjalanan yang cukup panjang artinya kondisi saat itu madrasahmadrasah ini membutuhkan tenaga pendidik yang mau mengabdi untuk mengembangkan pendidikan di lembaga pendidikan tersebut. Dan latar belakang pendidikan S1 mereka itupun adalah salah satu pilihan yang harus mereka lakukan mengingat belum adanya perguruan tinggi terdekat yang sesuai dengan bidang studi yang mereka ampu.

2. Porblematika alumni PAI sebagai guru kelas Madrasah Ibtidaiyah sekecamatan Pangkalan Susu masih merasa kesulitan untuk menyusun rencana pelaksanaan pembelajaran secara mandiri. Disamping itu ketiga Madrasah Ibtidaiyah ini juga belum memiliki perpustakaan yang dapat menyediakan buku-buku yang mumpuni untuk bisa dijadikan sebagai sumber belajar.

3. Problematika alumni PAI sebagai guru kelas Madrasah Ibtidaiyah dalam melaksanakan pembelajaran di kecamatan Pangkalan adalah kesamaan guru dalam metode pembelajaran dan kurangnya penguasaan materi. Hal ini disebabkan kurangnya pengetahuan mereka tentang variasi metode pembelajaran, di pihak lain jarangnya guru-guru ini mengikuti pelatihan, seminar, work shop yang dapat memberikan informasi untuk perkembangan bagi profesi mereka.

4. Problematika alumni PAI sebagai guru kelas Madrasah Ibtidaiyah dalam melakukan evaluasi pembelajaran di kecamatan Pangkalan Susu kabupaten Langkat adalah belum memenuhi prosedur penilaian. Hal ini disebabkan guru tidak melakukan perubahan dalam penyampain materi kepada peserta didik atau guru belum mampu merencanakan pelaksanaan pembelajaran atau menyusun RPP secara mandiri yang merupakan titik awal dari evaluasi pembelajaran. 
Selanjutnya berdasarkan uraian pada hasil studi penelitian tentang problematika alumni PAI sebagai guru kelas di kecamatan Pangkalan Susu, akhirnya peneliti memberikan beberapa rekomendasi penting yaitu:

1. Hendaknya bagi kepala madrasah memperhatikan keahlian guru dalam mengajar, jangan karena hanya mengakomodasi berbagai kepentingan kemudian dengan menempatkannya tidak pada posisi pelajaran yang menjadi keahliannya.

2. Alumni PAI yang telah menjadi guru kelas senantiasa berusaha untuk terus meningkatkan kemampuan kompetensi pedagogi dan profesional dengan mengikuti pelatihan, seminar, atau workshop yang dapat meningkatkan wawasan dan kompetensi mereka dalam merencanakan pembelajaran sesuai tujuan pembelajaran.

3. Alumni PAI yang telah mengampu guru kelas harus banyak belajar untuk mendalami materi-materi pengajaran yang belum dikuasainya sebelum melaksanakan pembelajaran dengan banyak membaca dan mengambil langkahlangkah progresif secara praktis dengan memperkuat kompetensi ilmu, bahkan mengikuti salah satu program peningkatan kualifikasi sarjana (S1) yang sesuai dengan bidang studi yang diampunya.

\section{DAFTAR PUSTAKA}

Azra, Azyumardi. Pendidikan Islam Tradisi dan Modernisasi Menuju Milenium Baru. Ciputat: PT Logos Wacana Ilmu. 1999

Hamalik, Oemar. Proses Belajar Mengajar. Jakarta: Bumi Aksara, 2004.

http://www.faktakampus.com/2017/11/prospek-kerja-pai-pendidikan-agama.html diakses 26 Juni pukul 20.50 WIB

ejournal.uin-suka.ac.id/tarbiyah/index.php/jpai/article/view/.../1177 diakses 26 Mei 2014 pukul 04.00 WIB

eprints.ums.ac.id/58334/1/Naskah\%20Publikasi.pdf diakses 28 Mei 2018 pukul 14.25 WIB

fkip.unira.ac.id/wp-content/uploads/...JURNAL-PORTAL-3.pdf diakses 04 Juli 2018 pukul 20.56 WIB

https://ejournal.kopertis10.or.id/index.php/curricula/article/.../pdf diakses 10.00 WIB 18 mei 2018)

http://eprints.ums.ac.id/47345/22/naskah\%20publikasi-ok.pdf

http://winarno.staff.iainsalatiga.ac.id/wp-content/uploads/sites/25/2013/01/34-

Evaluasi-Pembelajaran.pdf diakses 18 Mei 2018 pukul 16.00

http://www.journal.walisongo.ac.id/index.php/attaqaddum/article/view/723 diakses 24 Mei 2018 pukul 14.30

http://jurnaltarbiyah.uinsu.ac.id/index.php/nizhamiyah/article/view/257/243 diskeses $\underline{26 \mathrm{Mei} 2015 \text { pukul 05.10. }}$. 